\title{
Seasonal Incidence of Insect-pests of Soybean and their Correlation with Abiotic Factors
}

\author{
Nikki Bhardwaj $^{1 *}$, Bhavna Verma ${ }^{2}$ and Praveen Bhardwaj ${ }^{1}$ \\ ${ }^{1}$ Jagannath University, Jaipur (Raj), India \\ ${ }^{2}$ Dr. B.R. Ambedkar University of Social Science, Mhow (MP), India \\ *Corresponding author
}

\begin{abstract}
Keywords
Weather factors, blue beetle,

Tobacco caterpillar and Correlation and regression

Article Info

Accepted:

07 March 2019

Available Online:

10 April 2019 week of June, 2015-16 in an area of $200(20 \times 10 \mathrm{~m})$ square meters following the recommended agronomical practices with the spacing of $40 \times 10 \mathrm{~cm}$ rows and plants, respectively. The observations on the appearance of major insect pests were recorded from germination to harvest of the crop at weekly intervals at 10 different sites in 1 meter row length from each site once in a week and correlation was worked out. For blue beetle per cent infestation and for tobacco caterpillar, larval population was counted. Blue beetle infestation started in $26^{\text {th }}$ MSW with $1.3 \%$ damage. The infestation increased and reached its peak as $7.5 \%$ in $32^{\text {th }}$ SMW ending $31^{\text {th }}$ August. After that the infestation decreased slowly in next two weeks and noted least as $3.1 \%$ in $33^{\text {th }}$ SMW ending $7^{\text {th }}$ September. The occurrence of tobacco caterpillar started with $2.5 \%$ insects in $29^{\text {th }}$ SMW ending $10^{\text {th }}$ august. The population fluctuated and reached its peak as $14.5 \%$ in $35^{\text {th }}$ SMW ending $21^{\text {st }}$ September. Both the insects significant negative correlation with maximum temperature (blue beetle, $r=-0.667$ and tobacco caterpillar, $r=-0.528$ ). Blue beetle significant positive correlation with rain fall and rainy day (Rainfall $r=0.572$ and Rainy day, $r=0.572$ ) and tobacco caterpillar significant positive correlation with morning humidity was recorded. Rest of the abiotic factors exhibited non significant positive or negative correlation for both insects.
\end{abstract}

\section{A B S T R A C T}

A field experiment was conducted during kharif crop season 2015-16 at college of agriculture, Indore (M.P.) on cultivar RVS 2001-4 to assess the effect of weather factors on the trend of blue beetle and tobacco caterpillar activities. The crop was sown in second

\section{Introduction}

Soybean (Glycine max (L.) Merril) is known as the "Golden Bean" of the twentieth century. It has emerged as an important commercial crop in many countries and international trade of soybean is spread globally. Though soybean is a legume crop, yet it is widely used as oilseed. It can be grown on a variety of soil and in a wide range of climate. Soybean is a kharif crop in India, sown in June-July and harvested in late September-October.

Nationally soybean occupies an area of 108.39 lakh ha and its production is 114.83 lakh MT. Madhya Pradesh ranks first in total area (54.09 lakh ha and 51.50\%) and 
production (59.170 lakh MT and 70.06\%) in the country and is known as "soya state" in India (SOPA 2018).

The luxuriant crop growth, soft and succulent foliage attracts many insects and provides unlimited source of food, space and shelter. More than 150 insect pests cause damage to soybean in various parts of Madhya Pradesh in different stages of crop, and damage due to these insect-pests is one of major constrains for soybean production. The incidence of blue beetle and semilooper is a severe problem in the region and causes maximum loss in foliage and finally in yield. Global climatic changes, has now compelled the scientific community to study the effect of abiotic factors on insect pests presence and their trend of occurrence to manage them in systematic manner. Viewing the above situations the experiment was planned to know the occurrence of blue beetle and tobacco caterpillar relating with various weather parameters.

\section{Results and Discussion}

\section{Population dynamics of blue beetle in} soybean

The observations on blue beetle populations were started from $26^{\text {th }}$ SMW ending $29^{\text {th }}$ June. The insect population ranged from 1.3 to 7.5 during the season. The occurrence of insect started with 1.3 insects in $26^{\text {th }}$ SMW ending 29th June and it remained throughout the crop growth, when the weather factor i.e., maximum temperature, minimum temperature, humidity, rainfall, rainy days and wind velocity were $32.57^{\circ} \mathrm{C}, 23.86^{\circ} \mathrm{C}$, $88.57 \%, 74.2 \mathrm{~mm}, 3$ days and $9.34 \mathrm{~km} / \mathrm{h}$ respectively. The population fluctuated and reached its peak as 7.5 insects in $32^{\text {nd }}$ SMW ending 10th August (Table 1) when the maximum temperature, minimum temperature, humidity, rainfall, rainy days and wind velocity were recorded as $27.14^{\circ} \mathrm{C}$, $21.57^{0} \mathrm{C}, 92.14 \%, 282.4 \mathrm{~mm}, 5$ days and 9.34 $\mathrm{km} / \mathrm{hr}$ respectively.

\section{Correlation studies}

Correlation between population of blue beetle, and weather factors i.e. temperature (minimum and maximum), morning humidity, rainfall, rainy days and wind velocity were worked out. The ' $r$ ' value of deferent correlated factors expressed that (Table 2) significant positive correlation was found between rainfall $(\mathrm{r}=0.572)$, rainy days $(\mathrm{r}=0.572)$, and non significant positive correlation was noted with minimum temperature $(r=0.031)$ and wind velocity $(r=$ $0.445)$. The significant negative correlation was observed with maximum temperature $(r=-$ 0.667) and non significant negative correlation with morning humidity $(r=-0.060)$, and population of blue beetle. It exhibited that if the minimum temperature, morning humidity, rainfall, rainy days and wind velocity will increases or decreases from mean value then the population of blue beetle will also be increased or decreased respectively.

\section{Population dynamics of tobacco caterpillar in soybean}

The observations on tobacco caterpillar populations were started from $26^{\text {th }}$ SMW ending $29^{\text {th }}$ June in Soybean. The pest population ranged from 2.3 to 14.5 during $30^{\text {th }}$ to $38^{\text {th }} \mathrm{SMW}$. The occurrence of insect started with 7.2 insects in $30^{\text {th }}$ SMW ending 27 th July and it remained throughout the crop growth, when the weather factor i.e., maximum temperature, minimum temperature, humidity, rainfall, rainy days and wind velocity were $25.43{ }^{0} \mathrm{C}, 23.57^{\circ} \mathrm{C}$, $93.00 \%, 170.1 \mathrm{~mm}, 6$ days and $6.4 \mathrm{~km} / \mathrm{h}$ respectively. The population fluctuated (Table 1) and reached its peak as 14.5 insects in $35^{\text {th }}$ 
SMW ending $31^{\text {st }}$ August when the maximum temperature, minimum temperature, humidity, rainfall, rainy days and wind velocity were recorded as $31.29{ }^{0} \mathrm{C}, 23{ }^{0} \mathrm{C}, 91 \%, 1 \mathrm{~mm}, 1$ days and $6.63 \mathrm{~km} / \mathrm{hr}$ respectively

Table.1 Seasonal incidence of major insect pests of soybean during kharif 2015-16

\begin{tabular}{|c|c|c|c|}
\hline Period & SMW & Blue beetle population & $\begin{array}{c}\text { tobacco caterpillar } \\
\text { Population }\end{array}$ \\
\hline 23-29 June & 26 & 1.3 & 0.0 \\
\hline 30 June-6 July & 27 & 1.9 & 0.0 \\
\hline 7-13 July & 28 & 2.8 & 0.0 \\
\hline 14-20July & 29 & 2.9 & 5.0 \\
\hline 21-27July & 30 & 4.3 & 7.2 \\
\hline 28July-3 Aug & 31 & 5.8 & 9.3 \\
\hline 4-10Aug & 32 & 7.5 & 6.4 \\
\hline 11-17 Aug & 33 & 3.1 & 5.8 \\
\hline 18-24 Aug & 34 & 0.0 & 8.5 \\
\hline 25-31Aug & 35 & 0.0 & 14.5 \\
\hline 1-7Sep & 36 & 0.0 & 7.6 \\
\hline 8-14Sep & 37 & 0.0 & 3.8 \\
\hline 15-21Sep & 39 & 0.0 & 2.3 \\
\hline
\end{tabular}

Table.2 Correlation coefficient of blue beetle\& tobacco caterpillar infestation with abiotic factors in soybean

\begin{tabular}{|c|c|c|c|}
\hline S.No. & Weather parameters & $\begin{array}{l}\text { Correlation coefficient of } \\
\text { Blue beetle population }\end{array}$ & $\begin{array}{l}\text { Correlation coefficient } \\
\text { of tobacco caterpillar }\end{array}$ \\
\hline \multirow[t]{3}{*}{1} & Temperature $\left({ }^{\circ} \mathrm{C}\right)$ & & \\
\hline & Maximum & -0.6670 & -0.5287 \\
\hline & Minimum & 0.0313 & -0.3254 \\
\hline 2 & Morning humidity (\%) & -0.0608 & 0.5147 \\
\hline 3 & Rainfall (mm) & 0.5726 & 0.0135 \\
\hline 4 & Rainy day & 0.5724 & 0.2763 \\
\hline 5 & Wind velocity $(\mathbf{k m} / \mathbf{h r})$ & 0.4456 & -0.1839 \\
\hline
\end{tabular}

Significant at 5\% level

\section{Correlation studies}

Correlation between population of tobacco caterpillar and weather factors i.e. temperature (minimum and maximum), morning humidity, rainfall, rainy days and wind velocity were worked out. The ' $r$ ' value of deferent correlated factors expressed that (Table 2) significant negative correlation (Table 2) was found with maximum temperature $(\mathrm{r}=-0.606)$, and non significant negative correlation with minimum temperature $(\mathrm{r}=-0.161)$ and wind velocity $(\mathrm{r}=$ $-0.198)$ while significant positive correlation was found with morning humidity $(r=0.502)$ and non significant positive correlation with 
rainfall $(r=0.210)$, and rainy days $(r=0.377)$. Other weather factors exhibited non significant impact on insect population. Shali and Khadwe (2014) observed the appearance of the tobacco caterpillar during last week of july and disappeared during first week of October. Ahirwar and Payal (2015) observed the peak activity of green semilooper, Chrysodeixis acuta; (0.7 larvae per meter row) during second fortnight of August. Yeotikar and More (2015) observed that the green semiloooper recorded a peak of 3.00 larvae/mrl during $34^{\text {th }} \mathrm{MW}$. Ahirwar and Marabi (2014) recorded the peak larval population of tobacco caterpillar (Chrysodexis acuta) at $34^{\text {th }} \mathrm{SW}$ when maximum and minimum temperature was $32^{\circ} \mathrm{C}$ and $28.2^{\circ} \mathrm{C}$, respectively. There was no significant correlation exhibited between the larval population and weather parameters. Yadav and Banerjee (2015) observed that the population of semilooper decreased with increase in rainfall and $\mathrm{RH}$. Yadav and Agnihotri (2015) observed that maximum level of Trichoplusi $n i$ population attained during 39thSW showed significant positive correlation with minimum temperature and evening relative humidity in black gram. Kalyan and Ameta (2017) The maximum incidence of tobacco caterpillar in soybean crop was recorded during 41st SMW and 42nd SMW, respectively. The maximum temperature and sun shine hours showed a significant positive correlation with the larval population of tobacco caterpillar while, significant negative correlation with rainfall during both the years. Whereas, maximum temperature had significant positive impact on population of tobacco caterpillar while rainfall had significant negative effect.

S. Ramesh babu et al., (2017) observed that semilooper larval population was recorded late July/early August and their peak activity observed during 33-34, 33-36 and 37-39 standard weeks, in 2012, 2013 and 2014, respectively. Among the weather factors, morning relative humidity showed significant $(\mathrm{r}=0.954)$ and positively, highly influence on the larval population per mrl whereas evening humidity ( $\mathrm{r}=-0.644)$ and sunshine hrs ( $\mathrm{r}=-$ $0.367)$ negatively and significantly influence the larval population per mrl. The various weather parameters significantly caused 92 per cent variations in larval population per mrl. The findings of these researchers are in partial agreement as they did not study completely similar to present investigation. Further the climatic conditions vary place to place which affect the activities of insect pests.

\section{References}

Ahirwar, K.C., Marabi R.S and Bhowmick A.K. (2014). Population dynamics of major Insect Pests and seed yield of Soybean. Ann. of Pl. Protec. Sci., 22(1): 56-59.

Ahirwar, R., Devi P. and Gupta R. (2015). Seasonal incidence of major insectpests and their biocontrol agents of soybean crop (Glycine max L. Merrill). Department of Entomology IGKV, Raipur, 10(12): 402-406.

Kalyan, R.K. and Ameta O.P. (2017) Impact of abiotic factors on seasonal incidence of insect pests of soybean. Legume Research An International $J$. 40(4) 762-767.

Ramesh babu, Prahlad Kumar Meena and Ramgopal Dudwal (2017) Population dynamics of major defoliators (semiloopers and tobacco caterpillar) in soybean crop. J. of Legume Research, 40 (1) 2017: 183-186.

Shali Raju, G., Khandwe Nanda. and Nema K.K. (2014). Seasonal incidence, biology and behaviour of green semilooper, Chrysodeixis acuta (Walker) on Soybean. Ann. Of pl. prote. Sci., 22(2): 306-309. 
SOPA (2018). Estimates of area, productivity $\&$ production of soybean in India and MP. During Kharif. The soybean processors association of India. PP.14.

Yadav, P., Banerjee S., Gupta M. P. and Yadav V. K. (2015). Effect of Weather Factors on Seasonal Incidence of Insect-Pests of Soybean. J. of multidisciplinary advance research, 4(1): 46-51.

Yadav, S.K., Agnihotri M. and Bisht R.S.
(2015). Seasonal incidence of insectpests of black gram, Vigna mungo (Linn.) and its correlation with abiotic factors. Agric.sci. digest., 35(2): 146148.

Yeotikar S.G., More D.G., Chav R.D. and Gaikwad B.B. (2015). Correlation and regression between weather parameters and major insect pests of soybean. Journal of Entomological Research, 39(3): 227-230.

\section{How to cite this article:}

Nikki Bhardwaj, Bhavna Verma and Praveen Bhardwaj. 2019. Seasonal Incidence of Insectpests of Soybean and their Correlation with Abiotic Factors. Int.J.Curr.Microbiol.App.Sci. 8(04): 752-756. doi: https://doi.org/10.20546/ijcmas.2019.804.082 